Mehmet Demirci ${ }^{1}$

Yiğit Celepler ${ }^{2}$

Şölen Dincer ${ }^{3}$

İrem Yildirim ${ }^{2}$

Hatice Nur Çiğrikci²

Nursena Kalyenci ${ }^{2}$

Necmi Namal ${ }^{4}$

Hrisi Bahar Tokman ${ }^{5}$

Emine Mamal ${ }^{6}$

Sebahat Aksaray ${ }^{\top}$

Orhan Cem Aktepe ${ }^{2}$

Müzeyyen Mamal Torun²

\title{
Should we leave the paper currency? A microbiological examination
}

${ }^{1}$ Beykent University, School of Medicine, Department of Medical Microbiology, Istanbul, Turkey

${ }^{2}$ Bahcesehir University, School of Medicine, Department of Medical Microbiology, Istanbul, Turkey

${ }^{3}$ University of Health Sciences, Umraniye Education and Research Hospital, Medical Microbiology, Istanbul, Turkey

${ }^{4}$ Beykent University, School of Medicine, Department of Public Health, Istanbul, Turkey

${ }^{5}$ Istanbul University-Cerrahpasa, Cerrahpaşa School of Medicine, Department of Medical Microbiology, Istanbul, Turkey

${ }^{6}$ Istanbul University-Cerrahpasa, Cerrahpaşa School of Medicine, Department of Histology and Embryology, Istanbul, Turkey

${ }^{7}$ University of Health Sciences, Haydarpasa Numune Education and Research Hospital, Medical Microbiology, Istanbul, Turkey

\section{Article history}

Received: 23 October 2019; Revision Requested: 4 December 2019; Revision Received: 6 December 2019; Accepted: 7 January 2020; Published: 17 February 2020

\section{ABSTRACT}

Objetives. Pathogens can be transmitted to banknotes due to the personal unhygienic habits. The aim of study was to find the possible pathogens on the banknotes circulating in the market and also to present their antibacterial resistance and their various virulence factors using genotypic and phenotypic methods.

Material and methods. A total of 150 samples of banknotes were randomly collected between August 2017 and March 2018. VITEK systems were used for identification and antimicrobial susceptibility testing respectively. Antimicrobial resistance genes ( $m e c A$, van, extended-spectrum $\beta$-lactamase $[\mathrm{ESBL}]$ and carbapenemases) and staphyloccoccal virulence genes (staphyloccoccal enterotoxins [SEs], pvl, and tsst-1) were determined using with real-time PCR.

Results. Staphylococcus aureus, coagulase-negative staphylococci (CoNS), Enterococcus spp., Gram-negative enteric bacteria, non-fermentative Gram-negative bacteria and Candida spp. were detected 48\%, 54.7\%, 56\%, 21.3\%, 18.7\%, and $4 \%$, respectively. Methicillin-resistant S. aureus, vancomycin-resistant enterococci and ESBL producing Gram-negative were found $46.8 \%, 1.3 \%$, and $28.7 \%$, respectively. PVI, tsst-1, and SEs genes were found in a 2.8/4.9\%, 1.4/1.2\%, and 100/ $87.8 \%$ of the $S$. aureus/CoNS strains, respectively. The sea gene was found the most common enterotoxigenic gene. bla TEM $_{\text {, }}$ b/a $a_{\mathrm{SHV}}, b / a_{\mathrm{CTX}-\mathrm{M}-2,} b / a_{\mathrm{CTX}-\mathrm{M}-1}, b / a_{\mathrm{KPC}}$ and $b / a_{0 \times \mathrm{XX}-48}$ were found $55.8 \%, 46.5 \%, 41.2 \%, 18.6 \%, 18.6 \%$, and $18.6 \%$, respectively in Gram-negative strains.

Conclusion. These results is very important to highlight hygienic status of paper currencies. This can be considered as

Correspondence:

Mehmet Demirci

Beykent University School of Medicine

Department of Medical Microbiology, 34520, Istanbul, Turkey.

Phone: +905337106295.

E-mail: demircimehmet@hotmail.com an indication that banknotes may contribute to the spread of pathogens and antimicrobial resistance. Therefore, we may need to start using alternative products instead of banknotes.

Key-words: Paper currency; Bacterial contamination; Antimicrobial resistance genes; Staphyloccoccal enterotoxins

\section{¿Deberíamos dejar de usar los billetes? Análisis microbiológico}

\section{RESUMEN}

Objetivo. Los patógenos se pueden transmitir a los billetes debido a los hábitos antihigiénicos personales. El objetivo del estudio fue buscar los posibles patógenos en los billetes que circulan en el mercado y también observar su resistencia antibacteriana asi como sus diversos factores de virulencia utilizando métodos genotípicos y fenotípicos.

Material y métodos. Se recogieron al azar un total de 150 muestras de billetes entre agosto de 2017 y marzo de 2018. Se utilizaron los sistemas VITEK para la identificación y las pruebas de sensibilidad a los antimicrobianos, respectivamente. Los genes de resistencia a los antimicrobianos (mecA, van, betalactamasas de espectro ampliado [BLEA] y carbapenemasas) y los genes de virulencia estafilocócica (SE, pvl y tsst -1) se determinaron mediante PCR a tiempo real.

Resultados. Se detectó la presencia de cepas de Staphylococcus aureus, Staphylococcus coagulasa negativos (SCN), Enterococcus spp, bacterias gramnegativas, bacterias gramnegativas no fermentativas y Candida spp en un 48\%, 54,7\%, 56\%, $21,3 \%, 18,7 \%$ y $4 \%$ de los billetes, respectivamente. Se observó la presencia de $S$. aureus resistente a meticilina, Enterococcus resistentes a vancomicina y gramnegativos productores de BLEA en un $46,8 \%, 1,3 \%$ y $28,7 \%$, respectivamente. Los genes Pvl, tsst-1 y SE se encontraron en un 2,8/4,9\%; 1,4/1,2\% y $100 / 87,8 \%$ de las cepas de $S$. aureus/SCN, respectivamente. El gen sea fue el gen enterotoxigénico más frecuente. Los genes 
bla $a_{\mathrm{TEM}}, b / a_{\mathrm{SHV}}, b / a_{\mathrm{CTX}-\mathrm{M}-2}, b / a_{\mathrm{CTX}-\mathrm{M}-1}, b / a_{\mathrm{KPC}}$ y $b / a_{0 X \mathrm{XX}-48}$ se encontraron $55,8 \%, 46,5 \%, 41,2 \%, 18,6 \%, 18,6 \%$, y $18,6 \%$, respectivamente en cepas gramnegativas.

Conclusión. Estos resultados son muy importantes para resaltar el estado higiénico de los billetes. De este modo, los billetes pueden contribuir a la propagación de patógenos y de la resistencia a los antimicrobianos. Por lo tanto, es posible que debamos comenzar a utilizar productos alternativos a los billetes.

Palabras clave: Papel moneda; Contaminación bacteriana; Genes de resistencia, Antimicrobianos; Enterotoxinas estafilocócicas

\section{INTRODUCTION}

The hygienic status of banknotes has been a topic of speculation since the late 1800s [1]. In vitro culture studies have established that microbial contamination of paper currency is widespread, and that money represents an important human-microbe interface. Microbial contamination of paper money can ocur by money counting machines, atmosphere, dust, soil, storage process, during usage or production process [2]. Contamination during use is most often caused by handwashing after the toilet or false hand washing, by saliva counting, coughing and sneezing in hands. As a result, paper money is contaminated with microorganisms from the human hand, mouth and even in the gastrointestinal tract microbiota. As a result of the exchange of these contaminated banknotes among people, microorganisms begin to spread, contributing to the spread of both antibiotic resistance and many virulence factors and they pose a risk to public health $[2,3]$. Researches show that the most common microorganisms carried with paper money were enteric bacteria such as Salmonella spp., Shigella spp., Klebsiella spp. and Escherichia coli, Pseudomonas aeruginosa, Acinetobacter spp. and other non-fermentative Gram-negative bacilli, Staphylococcus aureus and other various Gram-positive cocci and various types of fungus such as Candida spp., Aspergillus spp., Penicillium spp. [2]. Humans are the most important source of Staphylococcus spp, especially $S$. aureus and S. epidermidis but also S. hominis, S. haemolyticus, S. saprophyticus, S. capitis, S. warneri, S. simulans and S. cohnii. The pathogenic capacity of these Staphylococcus spp. that can be easily transmitted to paper money is attributed to a combination of invasive properties, production of extracellular factors (like toxins) and antibiotic resistance. Staphylococcal toxins with superantigens characteristic include Panton-Valentin Leucocidin (PVL), toxic shock syndrome toxin 1 (TSST-1), exfoliative toxins (ETA to ETD) and staphylococcal enterotoxins (SEs) [4]. Staphylococcal food poisoning (SFP) is caused by the ingestion of food containing SEs produced by enterotoxigenic strains of coagulase-positive staphylococci (CPS), mainly $S$. aureus, although other CPS strains, such as $S$. hyicus, may also be enterotoxigenic $[4,5]$. Recently, the enterotoxigenic potential of coagulase-negative staphylococci (CoNS) species in food poisoning has also been recognized [5-8]. There are various publications which investigated the microorganisms carried by currency banknotes $[1-3,9,10]$. However, there is limited number of studies on the dissemination of antibiotic resistance by paper money in the literature. At the same time, it has been determined that there are no studies investigating the species of staphylococci that can be carried by paper money and investigating the important virulence factors of staphylococci such as PVL, TSST- 1 and SEs.

This study was planned in order to determine the microorganisms that can be transported with Turkish currency banknotes in Istanbul and to determine their role in the spread of antibiotic resistance and the potential effects of money on the spread of toxin genes by investigating the toxin genes of staphylococci.

\section{MATERIAL AND METHODS}

Bacterial isolates. A total of 150 samples of Turkish banknotes involving six denominations $(5,10,20,50,100$ and 200), 25 samples each, were randomly collected from hospital cafeteria, canteen of medical faculty, supermarkets near the hospital and restaurants, banks, buyers in open-air markets, and filling-stations in Istanbul, the most populated in Turkey from August 2017 to August 2018. The banknotes were obtained by using aseptic sampling method and banknotes were placed in a sterile polyethylene bag. The bag was sealed and the individual was given a replacement banknote, then all the collected samples were taken to the medical microbiology laboratory at the Medical School in Istanbul. Each banknote was placed in 10-mL of thioglicolat broth and shaken for 5-10 min on and subsequently incubated at $35-37^{\circ} \mathrm{C}$ for 48 hours. For isolation of bacteria, a sterile, cotton-tipped swab was introduced in the incubated thioglicolat broth and was then inoculated onto blood agar plates, Chromagar methicillin-resistant $S$. aureus (MRSA) and MacConkey agar plates and incubated at $35-37^{\circ} \mathrm{C}$ for 48 hours. For routine identification procedures automatized systems VITEK MS (BioMerieux, France) was used $[4,11]$. For identification of fungi, a loopful of incubated nutrient broth was inoculated onto Sabouraud dextrose agar plates and incubated at $22-25^{\circ} \mathrm{C}$ for $48-72$ hours. Identification of fungal isolates was based on growth characteristics and the lacto-phenol cotton blue reaction [4]. The isolates were stored separately in tryptic soy broth medium with $15 \%$ glycerol at $-80^{\circ} \mathrm{C}$ for further phenotypic and genotypic analysis.

Phenotypic antibiotic susceptibility patterns of the Isolates. Phenotypic antimicrobial susceptibility testing was performed by VITEK 2 Compact (BioMerieux, France), and interpretation was done according to EUCAST-2016 guidelines [11]. MRSA isolates were defined as MRSA using a cefoxitin $30-\mu \mathrm{g}$ disk screening test and PCR (for mecA gene). S. aureus ATCC 25923 was used as quality control [11].

Suspected isolates of Enterococcus spp. were screened for vancomycin resistance. The concentration of vancomycin in vancomycin screening agar was $6 \mathrm{mg} / \mathrm{L}$. A swab which was dipped in a suspension of the isolate and then was deposited as a spot on the agar surface and it was incubated for 24 hours at $35^{\circ} \mathrm{C}$. Any growth after 24 hours was interpreted as vancomy- 
cin resistance $[4,11]$. For quality control, was used Enterococcus faecalis ATCC 29212 as a susceptible control and Enterococcus faecium ATCC 51299 as a resistant control.

Isolates of Gram-negative bacilli were inoculated on $\mathrm{MH}-$ agar plates. Discs containing respectively ceftazidime $(30 \mu \mathrm{g})$, cefotaxime $(30 \mu \mathrm{g})$, ceftriaxone $(30 \mu \mathrm{g})$ and aztreonam $(30 \mu \mathrm{g})$ disks were placed $20 \mathrm{~mm}$ (center to center) away from a disc containing a $20 \mu \mathrm{g}$ amoxicillin/10 $\mu \mathrm{g}$ clavulanic acid disk before overnight incubation at $37^{\circ} \mathrm{C}$. Extended-spectrum $\beta$-lactamase (ESBL) production was considered positive when the clavulanate mediated enhancement of the activity of an indicator drug produced a keyhole effect and regarded as a phenotypic confirmation of the presence of ESBL [11].

Molecular detection. Template DNA was prepared by a simple and rapid boiling procedure from suspension of $S$. aureus colonies [12]. DNA was collected and stored at $-20^{\circ} \mathrm{C}$ until real-time PCR runs.

a) Molecular detection of staphyloccoccal mec $A$ genes. Real-time polymerase chain reaction (PCR) was used for detection of mecA (table 1). As positive controls, S. aureus ATCC BAA-41 was used. Light Cycler 480 Probe Master kit (Roche Diagnostics $\mathrm{GmBH}$, Mannheim, Germany) was used with these primers and probes on Light Cycler 480 II (Roche Diagnostics $\mathrm{GmBH}$, Mannheim, Germany) instrument according to the manufacturer's instructions [12]. Real-time PCR profile was used; denaturation step at $95^{\circ} \mathrm{C}$ for $10 \mathrm{~min}$, followed by 45 cycles, of $10 \mathrm{~s}$ at $95^{\circ} \mathrm{C}, 30 \mathrm{~s}$ at $55^{\circ} \mathrm{C}, 1 \mathrm{~s}$ at $72^{\circ} \mathrm{C}$.

Molecular detection of van genes in Staphylococcus spp., Enterococcus spp., and ESBL genes in Gramnegative strains. Primers of $\operatorname{vanA}$, vanB, vanC1, vanC2-C3 genes for Staphylococcus spp. and Enterococcus spp. and beta lactamase $\&$ carbapenemase $\left(b / a_{\mathrm{CTX}-\mathrm{M} 11}, b / a_{\mathrm{CTX}-\mathrm{M} 2,}, b / a_{\mathrm{KPC}}, b / a_{0 X \mathrm{XA}-48,}\right.$

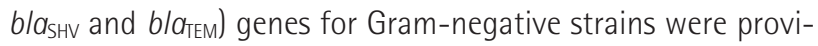
ded from Integrated DNA Technologies (IDT, Coralville, IA) (table 1) [13-16]. Light Cycler 480 Sybr Green I Master kit (Roche Diagnostics $\mathrm{GmBH}$, Mannheim, Germany) was used with these primers on Light Cycler 480 II (Roche Diagnostics GmBH, Mannheim, Germany) instrument according to the manufacturer's

\begin{tabular}{|c|c|c|c|}
\hline \multirow{2}{*}{$\begin{array}{c}\text { Table } 1 \\
\text { Name }\end{array}$} & \multicolumn{3}{|c|}{$\begin{array}{l}\text { rimers used for mecA, van, ESBL and carbapenemase genes presence in } \\
\text { he real-time PCR assay }\end{array}$} \\
\hline & Name & Oligonukleotid sequence & Ref. \\
\hline \multirow{3}{*}{$\begin{array}{l}\text { mecA primers for } \\
\text { Staphylococcus }\end{array}$} & MecAF & 5-GGCAATATTACCGCACCTCA-3 & McDonald et al, 2005 [12] \\
\hline & MecA R & 5-GTCTGCСАСТTСТССТTGT-3 & McDonald et al, 2005 [12] \\
\hline & MecA probe & 5-FAM- AGATCTATGCAAACTTAATGGCAAATCC-Tamra-3 & McDonald et al, 2005 [12] \\
\hline \multirow{8}{*}{$\begin{array}{l}\text { van gene primers for } \\
\text { Enterococcus spp. and } \\
\text { Staphylococcus spp. }\end{array}$} & $\operatorname{vanA} F$ & 5-AATACTGITTGGGGGTGGCTC-3 & Khan et al, $2005[13]$ \\
\hline & $\operatorname{vanA} R$ & 5-CTाTTCCGGCTCGACTCCT-3 & Khan et al, 2005 [13] \\
\hline & $\operatorname{vanB} F$ & 5-GCGGGGAGGATGGTGCGATACAG-3 & Khan et al, 2005 [13] \\
\hline & $\operatorname{van} B R$ & 5-GGAAGATACCGTGGCTCAAAC-3 & Khan et al, 2005 [13] \\
\hline & $\operatorname{vanC1~} \mathrm{F}$ & 5-ПTGACCCGCTGAAATATGAAGTAA-3 & Khan et al, 2005 [13] \\
\hline & $\operatorname{vanC1} \mathrm{R}$ & 5-TAGAACCGTAAGCAAAAGCAGTCG-3 & Khan et al, 2005 [13] \\
\hline & vanC2-C3 F & 5-GCATGGCAAATACGGGGAAGAT-3 & Khan et al, 2005 [13] \\
\hline & vanC2-C3 R & 5-CATGGCAGGATAGCGGGAGTGA-3 & Khan et al, 2005 [13] \\
\hline \multirow{12}{*}{$\begin{array}{l}\text { ESBL and carbapenemase } \\
\text { genes primers for } \\
\text { Gram-negative bacilli }\end{array}$} & blaCTX-M-1 & 5-GCGTGATACCACTTСACCTC-3 & Copur et al, 2013 [14] \\
\hline & & 5-TGAAGTAAGTGACCAGAATC-3 & \\
\hline & blaCTX-M-2 & 5- TGATACCACCACGCCGCTC-3 & Copur et al, 2013 [14] \\
\hline & & 5-TATGGATCAGAAACCGTGGG-3 & \\
\hline & blaKPC & 5- CGПСTGTCTCTCATGGCC-3 & Poirel et al, 2004 [15] \\
\hline & & 5- СCTCGCTGTGCTTGTCATCC-3 & \\
\hline & bla0XA-48 & 5- TGGTGGCATCGATATCGG-3 & Poirel et al, 2004 [15] \\
\hline & & 5- GAGCACTCTITTGTGATGGC-3 & \\
\hline & blaSHV & 5- ATGCGITATATCGCCTGTG-3 & Copur et al, 2013 [14] \\
\hline & & 5-ПАGGGTGCCAGTGCTC-3 & \\
\hline & TEM & 5- AGTATTCAACATTTYCGTGT-3 & Copur et al, 2013 [14] \\
\hline & & 5- TAATCAGTGAGGCACCTATCTC-3 & \\
\hline
\end{tabular}




\begin{tabular}{|c|c|c|c|c|c|c|c|c|}
\hline \multirow{3}{*}{\multicolumn{2}{|c|}{$\begin{array}{l}\text { Table } 2 \\
\text { Microorganisms }\end{array}$}} & \multicolumn{7}{|c|}{$\begin{array}{l}\text { Frequency distribution [\%] of microorganisms isolated from } \\
\text { paper currencies }\end{array}$} \\
\hline & & & Paper & rencie & $=25$ ea & ther] & & \multirow[t]{2}{*}{ Total $[n=150]$} \\
\hline & & $5 f$ & $10 £$ & $20 £$ & $50 £$ & $100 £$ & $200 £$ & \\
\hline \multicolumn{2}{|c|}{ Bacillus spp. } & 20 & 17 & 14 & 14 & 12 & 13 & $90(60 \%)$ \\
\hline \multicolumn{2}{|c|}{ Corynebacterium spp. } & 4 & 4 & 1 & 2 & 1 & 2 & $14(9.3 \%)$ \\
\hline \multicolumn{2}{|c|}{ Staphylococcus aureus } & 14 & 12 & 10 & 11 & 10 & 15 & $72(48 \%)$ \\
\hline \multicolumn{2}{|c|}{ Coagulase negative staphylococci (CoNS) } & 21 & 17 & 15 & 14 & 9 & 6 & $82(54.7 \%)$ \\
\hline \multicolumn{2}{|c|}{ Streptococcus spp. } & 1 & 1 & 0 & 0 & 0 & 0 & $2(1.3 \%)$ \\
\hline \multicolumn{2}{|c|}{ Micrococcus spp. } & 2 & 1 & 1 & 0 & 0 & 0 & $4(2.7 \%)$ \\
\hline \multicolumn{2}{|c|}{ Enterococcus spp. } & 8 & 18 & 12 & 15 & 11 & 20 & $84(56 \%)$ \\
\hline \multicolumn{2}{|c|}{ Neisseria spp. } & 1 & 1 & 1 & 0 & 0 & 0 & $3(2 \%)$ \\
\hline \multicolumn{2}{|c|}{ Escherichia coli } & 2 & 0 & 0 & 0 & 0 & 2 & $4(2.7 \%)$ \\
\hline \multicolumn{2}{|c|}{ Enterobacter cloacae } & 10 & 2 & 1 & 1 & 1 & 0 & $15(10 \%)$ \\
\hline \multicolumn{2}{|c|}{ Pantoea agglomerans } & 1 & 0 & 3 & 3 & 2 & 0 & $9(6 \%)$ \\
\hline \multicolumn{2}{|c|}{ Klebsiella pneumoniae } & 2 & 1 & 0 & 0 & 1 & 0 & $4(2.7 \%)$ \\
\hline \multicolumn{2}{|c|}{ Klebsiella oxytoca } & 1 & 1 & 0 & 0 & 0 & 0 & $2(1.3 \%)$ \\
\hline \multicolumn{2}{|c|}{ Pseudomonas aeruginosa } & 4 & 2 & 2 & 1 & 1 & 0 & $10(6.7 \%)$ \\
\hline \multicolumn{2}{|c|}{ Pseudomonas putida } & 2 & 2 & 0 & 0 & 1 & 1 & $6(4 \%)$ \\
\hline \multicolumn{2}{|c|}{ Acinetobacter baumannii complex } & 9 & 3 & 1 & 0 & 0 & 2 & $15(10 \%)$ \\
\hline \multicolumn{2}{|c|}{ Candida spp. } & 0 & 0 & 3 & 2 & 0 & 1 & $6(4 \%)$ \\
\hline \multicolumn{2}{|l|}{ Total } & 102 & 82 & 64 & 63 & 49 & 62 & 422 \\
\hline
\end{tabular}

instructions. Real-time PCR profile was used; denaturation step at $95^{\circ} \mathrm{C}$ for $10 \mathrm{~min}$, followed by 35 cycles of amplification; $10 \mathrm{~s}$ at $95^{\circ} \mathrm{C}, 30 \mathrm{~s}$ at $52^{\circ} \mathrm{C}, 1 \mathrm{~s}$ at $72^{\circ} \mathrm{C}$ and melting curves; $5 \mathrm{~s}$ at $95^{\circ} \mathrm{C}$, 60s at $65^{\circ} \mathrm{C}$, and $97^{\circ} \mathrm{C}$ cont. reading). E. faecium ATCC 51559, E. faecalis ATCC 51299, E. gallinarum ATCC 49573, and E. casseliflavus ATCC 25788 strains were used as a positive control for vanA, vanB, vanC1, and vanC2-C3 genes respectively. K. pneumoniae ATCC 700603 and E.coli ATCC 25922 were also used as a control of beta lactamase and carbapenemase genes.

b) Molecular detection of SEs, pvl and tsst -1 genes. Real-time polymerase chain reaction (real-time PCR) was used for detection of specific genes to confirm their identities (such as SEs, pvl, and tsst-1 gene) via the primers previously described Peck et al [17]. Light Cycler 480 Sybr Green Master kit (Roche Diagnostics GmBH, Mannheim, Germany) was used with these primers on Light Cycler 480 II (Roche Diagnostics GmBH, Mannheim, Germany) instrument according to the manufacturer's instructions. $0.5 \mathrm{uM}$ primers were added in reactions of final concentrations. Real-time PCR profile was used; denaturation step at $95^{\circ} \mathrm{C}$ for $10 \mathrm{~min}$, followed by 40 cycles, of $10 \mathrm{~s}$ at $95^{\circ} \mathrm{C}$,
30 s at $55^{\circ} \mathrm{C}$, 1s at $72^{\circ} \mathrm{C}$ and melting curves; $5 \mathrm{~s}$ at $95^{\circ} \mathrm{C}$, 60 s at $65^{\circ} \mathrm{C}$, and $97^{\circ} \mathrm{C}$ cont. reading). As positive controls, S. aureus ATCC 13565 (sea, sej), S. aureus ATCC 14458 (seb), S. aureus ATCC 19095 (sec, seh), S. aureus ATCC 23235 (sed, seg, sei), S. aureus ATCC 27664 (see), S. aureus ATCC 25923 (pv), S. aureus ATCC 51650 (tsst-1) were used. As a nontoxigenic control $S$. aureus ATCC 6538 was used.

\section{RESULTS}

Of the 150 samples of Turkish currency banknotes on which bacteriological analysis was conducted, $81 \%$ were found to be contaminated with several microbial species. The spectrum of microbial species were detected at rates of; S. aureus 48\% (46.8\% MRSA and 1.2\% MSSA), CoNS 54.7\%, Enterococcus spp. $56 \%$, enteric bacteria $21.3 \%$, non-fermentative Gram-negative bacteria $18.7 \%$ and Candida spp. $4 \%$. A wide distribution of pathogens occurred from the different points included (table 2). The highest microbial contamination was obtained in the Turkish currency banknotes from the hospital cafeteria, followed by the cafeteria of medical faculty students. Others were with order supermarkets and restau- 
\begin{tabular}{|l|l}
\hline Table 3 & Identification of ESBL and carbapenemase genes in Gram-negative bacilli
\end{tabular}

\begin{tabular}{|c|c|c|c|c|c|}
\hline \multicolumn{6}{|c|}{ Bacteria (number of isolates/EBSL positive) } \\
\hline E. coli $(n=4 / 3)$ & K. pneumoniae $(n=4 / 4)$ & E. cloacae $(n=15 / 10)$ & P. agglomerans $(n=9 / 4)$ & A. baumannii $(n=15 / 12)$ & P. aeruginosa $(n=10 / 7)$ \\
\hline $\mathrm{TEM}+\mathrm{KPC}+\mathrm{SHV}$ & CTX-M-1 + OXA 48 & TEM & SHV & CTX-M-1 + 0XA-48 & CTX-M-1 + KPC \\
\hline (1 strain) & (1 strain) & (1 strain) & (1 strain) & (1 strain) & (1 strain) \\
\hline CTX-M-2 + TEM + SHV & CTX-M-2 + KPC & CTX-M-2 & CTX-M-2 + TEM + SHV & CTX-M-2 + 0XA-48 & CTX-M-1 + TEM + SHV \\
\hline (1 strain) & (1 strain) & (1 strain) & (2 strains) & (1 strain) & (1 strain) \\
\hline CTX-M-2 + TEM + OXA-48 + SHV & TEM + OXA-48 & CTX-M-2 + TEM & CTX-M-1 + CTX-M-2 + TEM & CTX-M-2 + TEM & CTX-M-2 \\
\hline \multirow[t]{9}{*}{ (1 strain) } & (1 strain) & (2 strains) & $+\mathrm{SHV}$ & (3 strains) & (1 strain) \\
\hline & TEM + OXA-48 + SHV & CTX-M-1 + TEM + SHV & (1 strain) & KPC & CTX-M-2 + TEM \\
\hline & (1 strain) & (1 strain) & & (2 strains) & (2 strains) \\
\hline & & TEM + SHV & & OXA-48 + SHV & TEM + OXA-48 \\
\hline & & (2 strains) & & (2 strain) & (1 strain) \\
\hline & & CTX-M-2 + TEM + SHV & & SHV & KPC \\
\hline & & (2 strains) & & (3 strains) & (1 strain) \\
\hline & & CTX-M-1 + CTX-M-2 + SHV & & & \\
\hline & & (1 strain) & & & \\
\hline
\end{tabular}

rants around the hospital, banks, buyers in open-air markets and filling-stations. In the Turkish currency banknotes, the most intensive bacterial contamination was found in $5 £$, followed by $10 £, 20 £, 50 £$ and $100 £$, respectively. When looking at $200 £ b a n k n o t e s$, the contamination rate was found to be higher than $100 £$. The species of Staphylococcus spp. 154 produced in the highest proportion were S. aureus 48\% and CoNS 54.7\%. The distribution of CoNS were S. epidermidis $46.7 \%$, S. haemolyticus 20\%, S. hominis $12.2 \%$, S. capitis $11 \%$, S. warneri $4.9 \%, S$. lugdunensis $3.7 \%$, S. caprae $2.4 \%$ and $S$. saprophyticus $2.4 \%$. The mecA gene was observed in $90.3 \%$ of S. aureus and in $73 \%$ of CoNS isolates. When the antibiotic resistance of Staphylococcus spp. were examined; the resistance rates in MRSA strains were erythromycin $66.7 \%$, clindamycin $22.2 \%$, gentamicin 16.7\%, trimethoprim+sulfamethoxazole (SXT) 16.7\%; In S. epidermidis, erythromycin 34.3\%, clindamycin 17.2\%, gentamicin 5.9\%, ciprofloxacin 5.9\% and SXT 5.9\%; in S. haemolyticus erythromycin $72.2 \%$, clindamycin $44.4 \%$, tigecycline 38.9\%, ciprofloxacin 38.9\% and linezolid 38.9\%; in S. hominis erythromycin 16.2\% and SXT 16.2\%; in S. capitis gentamicin 20\%. None of the staphylococci strains were found to have quinupristin/dalfopristin and vancomycin resistance. The rate of multi-drug resistance (resistance to more than three antibiotics-MDR) was found as 40.3\%.

The second most frequently isolated 84 Enterococcus spp. $(56.7 \%)$ was the distribution of bacteria in the species $E$. faecium 35 (41.7\%), E. faecalis 8 (9.5\%), E. casseliflavus 21 (25\%) and other Enterococcus spp. 10 (11.9\%), respectively. Vancomycin resistance was determined by both phenotypic and genotypic methods in two origins, one $E$. faecium and one $E$. casseliflavus (2.4\%). The resistance gene was vanA. Other van- comycin resistance genes were not detected. Enteric bacteria isolated from banknotes were 21.3\%. Enterobacter cloacae was the first line of enteric bacteria with $46.9 \%$. The others were Pantoea agglomerans $28.2 \%$, E. coli $12.5 \%$, K. pneumoniae and $K$. oxytoca $12.5 \%$, respectively. When the antimicrobial resistance in enteric bacteries was examined ampicillin was found to be with the highest resistance rate as $81 \%$. Resistance rates to other antibiotics were determined as follows: ceftazidime $75 \%$, cefuroxime and cefuroxime + axetil combination of $65.6 \%$ cefoxitine $62.5 \%$, cefepime $78 \%$, ceftriaxone $9.4 \%$, ertapenem, meropenem, imipenem $12.5 \%$, amikacin 25\%, gentamicin 22\%, ciprofloxacin 40.6\%, tigecycline 3\% trimethoprim-sulfamethoxazole $25 \%$, colistin $6.3 \%$. MDR in enteric bacteria was $40.6 \%$. ESBL enzyme genes were found to be $66.7 \%$ in enteric bacteria (table 3 ). Non-fermentative Gram-negative rods isolated from banknotes were 18.7\%. Among the non-fermentative bacteria, Acinetobacter baumannii complex ranked first with 53.6\%. The others were $P$. aeruginosa $35.7 \%$, $P$. puti$d a 10.7 \%$ and $P$. stutzeri $7.2 \%$ respectively. Antimicrobial resistance rates of Pseudomonas spp. were as piperacillin 50\%, piperacillin+ tazobactam 40\%, ceftazidime 40\%, ceftriaxone $30 \%$, imipenem 10\%, amikacin 20\% and ciprofloxacin 30\%. Antimicrobial resistance rates of Acinetobacter baumannii complex were as piperacillin 53.3\%, piperacillin+ tazobactam $40 \%$, ceftazidime $66.7 \%$, ceftriaxone $33 \%$, imipenem $26.7 \%$, amikacin 33\% ve ciprofloxacin 46.7\%. MDR was 60\% in $P$. aeruginosa and $76 \%$ in $A$. baumannii complex. ESBL enzyme genes were found to be $65.6 \%$ in enteric bacteria and $76 \%$ in non fermentative Gram-negative bacteria. The distribution by species was E. coli $75 \%$, K. pneumoniae 100\%, E. cloacae 66.7\%, P. agglomerans 44.4\%, P. aeruginosa $70 \%$ and A. bau- 


\begin{tabular}{|c|c|c|c|c|c|c|c|c|}
\hline \multirow[t]{2}{*}{ Table 4} & \multicolumn{8}{|c|}{ Status of mec $A$ and toxin genes of 154 Staphylococcus spp. isolates } \\
\hline & & & & & Number of positi & e isolates & & \\
\hline Bacterial isolates $(\mathrm{n})$ & mecA & Pvl & Tsst-1 & SES & Only one toxin gene & Multiple toxin gene & Toxigenic & Non-toxigenic \\
\hline S. aureus (72) & 65 & 2 & 1 & 72 & 1 & 71 & 72 & 0 \\
\hline CoNS (82) & 60 & 4 & 1 & 74 & 3 & 71 & 74 & 8 \\
\hline S. epidermidis (35) & 29 & 1 & 0 & 35 & 1 & 34 & 35 & 0 \\
\hline S. haemolyticus (17) & 8 & 1 & 0 & 12 & 1 & 11 & 12 & 5 \\
\hline S. hominis (10) & 9 & 1 & 0 & 10 & 1 & 9 & 10 & 0 \\
\hline S. capitis (9) & 7 & 0 & 0 & 9 & 0 & 9 & 9 & 0 \\
\hline S. warneri (4) & 3 & 1 & 1 & 4 & 0 & 4 & 4 & 0 \\
\hline S. lugdunensis (3) & 2 & 0 & 0 & 2 & 0 & 2 & 2 & 1 \\
\hline S. caprae (2) & 1 & 0 & 0 & 1 & 0 & 1 & 1 & 1 \\
\hline S. saprophyticus (2) & 1 & 0 & 0 & 1 & 0 & 1 & 1 & 1 \\
\hline Total (154) & 125 & 6 & 2 & 146 & 4 & 142 & 146 & 8 \\
\hline
\end{tabular}

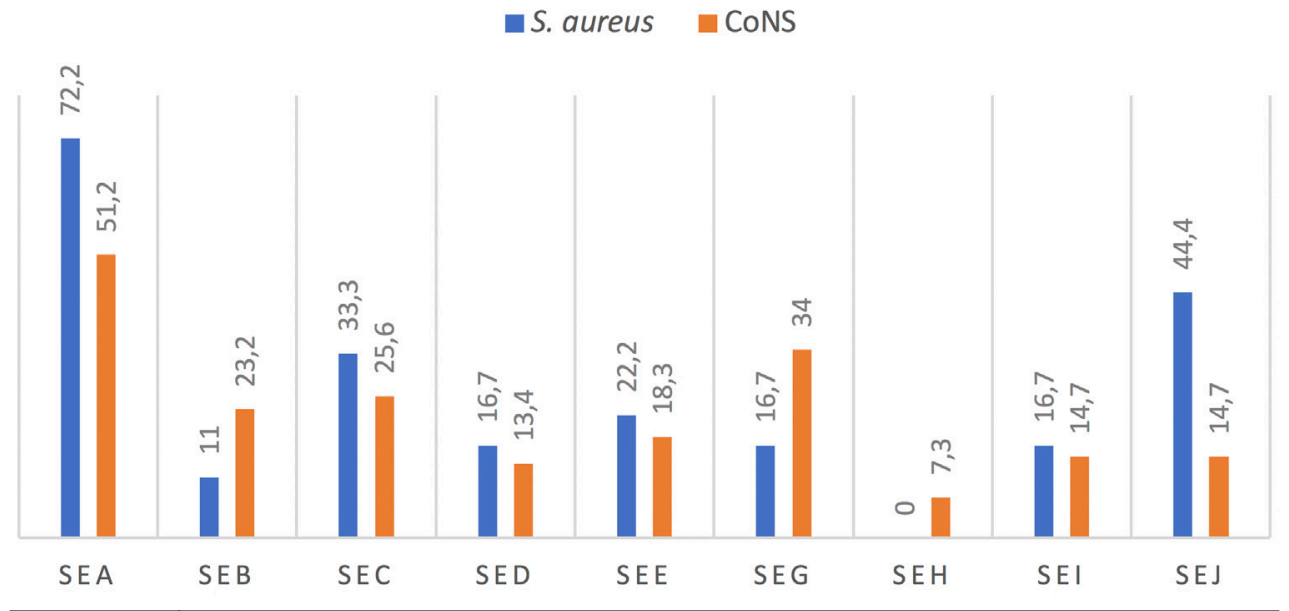

\begin{tabular}{l|l} 
Figure 1 & Distribution of SEs genes in S. aureus and CoNS
\end{tabular}

mannii 80\% (table 3). CTX-M type ESBL enzyme genes were found to be $43.8 \%$ in enteric bacteria and $40 \%$ in non fermentative Gram-negative bacteria. The distribution by species was E. coli 50\%, K. pneumoniae 50\%, E. cloacae 46.7\%, P. agglomerans 22.2\%, P. aeruginosa $50 \%$ and $A$. baumannii 33.3\%.

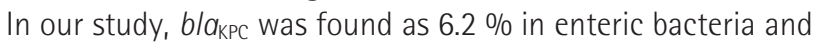
as $12 \%$ in non-fermentative bacteria. The distribution by species was E. coli 25\%, K. pneumoniae, 25\%, P. aeruginosa 20\% and $A$. baumannii 13.3\%. OXA-48 enzyme genes were found to be $12.5 \%$ in enteric bacteria and $20 \%$ in non-fermentative Gram-negative bacteria. The distribution by species was $E$. coli 25\%, K. pneumoniae 75\%, P. aeruginosa $10 \%$ and A. baumannii $26.7 \%$. The availability of toxin genes were $100 \%$ in S. aureus, $100 \%$ in S. epidermidis, $70.6 \%$ in S. haemolyticus, $66.7 \%$ in S. lugdunensis, 50\% in S. caprae and 50\% in S. saprophyticus. The distribution of toxin genes were pvl 2.8\%, tsst-1 $1.4 \%$ and SEs 100\% in S. aureus, pvl 4.9\%, tsst-1 1.2\% and SEs $87.8 \%$ in CoNS (table 4). The distribution of SEs genes in $S$. aureus were as sea $72.2 \%$, seb $11 \%$, sec $33.3 \%$, sed $16.7 \%$, see $22.2 \%$, seg $16.7 \%$, sei $16.7 \%$ and sej $44.4 \%$, the seh gene was not found. The distribution of SEs genes in CoNS were as sea $51.2 \%$, seb $23.2 \%$, sec $25.6 \%$, sed $13.4 \%$, see $18.3 \%$, seg $34 \%$, seh $7.3 \%$, sei $14.7 \%$ and sej $14.7 \%$ (figure 1). Comparing with that of CoNS, the sea gene was found statistically significantly high in S. aureus strains $(p<0.05)$ and comparing with that of S. aureus strains, the seb, seg and seh genes were found statistically significantly high in CoNS strains. 


\section{DISCUSSION}

Paper currencies are objects capable of absorbing, harboring and transmitting infectious microorganisms [2]. Researches show that the microbial load on banknotes varies according to the banknotes, seasons, stored under varying environmental conditions, the age of banknotes, the local community microbiota, the general hygiene level, and the general hygienic conditions $[3,9,10]$. The amount of bacterial contamination on currency varies widely between countries. Previous studies have revealed that $70-97 \%$ of banknotes harbor various bacteria and viruses on the surface in different nations such as the United States, Mexico, China, India, Saudi Arabia, Sudan, Pakistan, Brasil etc, $[9,10,18,19,20]$. In our study, Turkish currency banknotes on which bacteriological analysis was conducted, $81 \%$ were found to be contaminated with several microbial species. Our results show that similar results were obtained in previous studies. Numerous studies have shown that cotton-based banknotes have more microbial loads than polymer-based ones $[3,10]$.

Vriesekoop et al. reported that comparison of cotton-based banknotes of countries such as China, Ireland, The Netharlands, Nigeria, United Kingdom and the United States, as well as the polymer-based banknotes of countries such as Australia and New Zealand. They found that cotton-based banknotes had much more bacterial loading than polymer-based banknotes [3]. The bacterial load evaluated as $81 \%$ in Turkish banknotes can be explained by the fact that they are based on cotton. Some studies showed that, the longer the paper currencies remain in circulation, the more chance there is for them to become contaminated, and lower-denomination notes receive the most handling because they are exchanged more frequently $[2,3]$. According to our results also showed that health centers and health center workers and people who stay here play an important role contributing to the bacterial contamination. Many previous studies also claimed similar results $[2,3,9,10]$. Many bacteria have been isolated from banknotes in studies from Turkey, China, Philippines, India, Saudi Arabia, Mexico, New Zealand, Australia, Canada, USA and Europe. It was also reported that $S$. aureus, E. coli, Klebsiella spp. and Enterobacter spp. were identified from these countries' banknotes $[9,10]$. Staphylococcus spp. present in the nose often contaminate hands, fingers, faces, and nasal carriers which can easily become skin carriers [4]. In general, there was no obvious difference in survival between multiresistant and susceptible $S$. aureus strains. S. aureus (including MRSA) survive for 7 day -7 months on dry surfaces [21]. In our study, Staphylococcus spp. were the most isolated bacteria. Previous studies have also determined that there is a high number of Staphylococcus spp. on banknote, however, most studies did not identify Staphylococcus spp. Our study was the first research to identified Staphylococcus species unlike other researches on this topic. Methicillin resistance is an important consideration in all Staphylococcus spp., especially S. aureus. Global transmission of MRSA has been the subject of many studies $[3,22]$. In recent study, it was determined that the rate of methicillin resistant $S$. aureus was $90.3 \%$ and methicillin resistant in CoNS is 73.2\%. The highest antibiotic resistance in staphylococcus was erythromycin (72.2\%), and clindamycin (44.4\%) resistance in S. haemolyticus; gentamicin resistance (20\%) in S. capitis. Tigecycline (38.9\%), ciprofloxacin (38.9\%) and linezolid (33.3\%) resistance were found only in $S$. haemolyticus strains. None of the staphylococci strains had resistance to quinupristin/dalfopristin and vancomycin. The rate of MDR was found as $40.3 \%$. Recently, many published studies reported that $E$. faecium infections are increasing worldwide [4]. In our country, the rates of E. faecium and E. faecalis were determined to be $15-50 \%$ and $52-85 \%$, respectively [23, 24]. In previous researches, Enterococcus spp., which can be found without losing their vitality for 4 months in inanimate environments [21].

Many Gram-negative species, such as Acinetobacter spp., E. coli, Klebsiella spp., P. aeruginosa, Serratia marcescens, or Shigella spp. can survive on inanimate surfaces even for months. Overall, Gram-negative bacteria have been described to persist longer than Gram-positive bacteria $[3,21]$. Humid conditions improved persistence for most types of bacteria, such as Salmonella typhimurium, P. aeruginosa, E. coli or other relevant pathogens $[2,9,21,25]$. In previous studies, reported that Enterobacteraceae members are 13\%-55.5\% range of the paper currencies and the most frequently isolated enteric bacteria was E. coli (19.4-48.14\%) [2, 3, 9]. Antimicrobial resistance is a global phenomenon that has resulted in high morbidity and mortality as a result of treatment failures and increased health care costs. Research has shown that contaminated fomites in general and paper currency in particular, plays a key role in the spread of bacterial infections with antimicrobial resistance $[2,3,25]$. Heshiki et al. [22] in a metagenomic study showed that the antimicrobial resistance genes on banknotes were significantly higher (4.86 times more) than environmental samples such as water, air, soil and dust.

Emergence of glycopeptide resistance causes more severe prognosis, higher mortality, and recurrence in enterococcal infections. The most common type of enterococcal vancomycin resistance is high-level resistance associated with acquisition of the vanA and vanB genes, typically observed in E. faecium and E. faecalis isolates [4]. Conversely, the vanC genotype is associated with constitutive low-level vancomycin resistance and is intrinsic to E. gallinarum and E. casseliflavus [4]. In our study, vancomycin resistance was determined by both phenotypic and genotypic methods in two isolates (2.4\%), these were one E. faecium and one E. casseliflavus. The resistance genes were vanA. Other vancomycin resistance genes were not detected.

Resistance mediated by ESBLs includes all penicillins, cephalosporins (including third-generation cephalosporins) and aztreonam. Since plasmid-mediated ESBLs were first detected in a K. pneumoniae isolate in 1983 in Germany [26]. A new non-TEM non-SHV ESBL was isolated in Germany, in 1989, in a strain of E. coli called CTX-M because of its preferential activity on cefotaxime rather than ceftazidime [27]. Over the past 20 years, some Enterobacteriaceae mainly E. coli, K. pneu- 
moniae, and Proteus mirabilis have demonstrated acquisition of plasmids secreting ESBL [28]. In our study, the rates of ESBL enzyme genes were found to be high as 65.6\% in enteric bacteria and as 76\% in non-fermentative Gram-negative bacteria. CTX-M type ESBL enzyme genes were found to be $43.8 \%$ in enteric bacteria and 40\% in non-fermentative Gram-negative bacteria. Carbapenemases in Enterobacteriaceae are mainly found in K. pneumoniae, and to a much lesser extent in E. coli and other enterobacterial species, with a higher prevalence in southern Europe and Asia than in other parts of the World [28]. The first OXA-48 carbapenemase was identified in 2001 from a K. pneumoniae isolate obtained from a urine specimen collected in Istanbul, Turkey [15]. Shortly thereafter there was an outbreak of OXA-48 producing K. pneumoniae isolates reported in Istanbul in 2006 [29]. In our study, OXA-48 enzyme genes were found to be $12.5 \%$ in enteric bacteria and $20 \%$ in non fermentative Gram-negative bacteria. Staphylococcus spp. are also capable of producing "distant" diseases, which are mediated by the secretion of toxins and these toxins can be produced directly by bacteria that colonize the skin or mucosa or indirectly by microorganisms that colonize food, beverages and fomites $[4,30]$. Bacteriological studies about banknotes, have included no analysis of the toxin genes (pvl, tsst-1 and SEs). 95.4\% of Staphylococcus spp. that are analyzed from our study were determined to possess toxin genomes. The distribution of these toxin genomes was as follows: 3.9\% pvl, 1.3\% tsst- 1 and $98.4 \%$ SEs. There was no toxin genomes in the rest of the Staphylococcus spp. (5.2\%). PVL is a cytotoxin that causes tissue necrosis and leukocyte destruction. This linkage to virulent strains suggests its capability of causing deadly infections in healthy people [4]. Toxic shock syndrome (TSS) is a life-threatening illness characterized by high fever, erythematous rash with subsequent desquamation of the skin, shock, and multiple organ involvement $[4,31]$. In our study, it was possible to detect $1.3 \%$ of tsst-1 genomes from our isolated banknotes.

Six enterotoxins serotypes (sea to see and seh) have been involved in most of the Staphylococcus poisoning outbreaks worldwide [31]. In our study, it was indicated that $94.8 \%$ of Staphylococcus spp. have SEs genomes. S. aureus and CoNS strains can encode more than one enterotoxin gene simultaneously; over $50 \%$ of the isolates assessed showed this property [8]. All S. aureus strains were carried at least one SEs gene and the combination sea+sei, sea+sec+sei, sea+sed+sej was the most frequent. CoNS strains were positive SEs genome 90.2\% and the combination sea+sej, sea+sec+sej, sea+seg+sej, sea+ sed+seg+sei was the most frequent. sea is one of the most frequently observed enterotoxins, although the literature shows highly variable results in the prevalence of $S$. aureus enterotoxin genes, depending on the kind of food and the biovar investigated $[4,31]$. Compared to CoNS strains, sea genes were statistically significantly higher in $S$. aureus strains $(p<0.05)$. Compared to S. aureus strains, seb, seg and seh genes were statistically significantly high in CoNS strains $(p<0.05)$. On the other hand, the seh gene was detected at a rate of $7.3 \%$ in CoNS strains, although there was no in the $S$. aureus strains.
Several factors in the spread of pathogen and potential pathogenic bacteria, as well as antimicrobial resistance and virulance genes such as SES, community and hospital enviroments, animal products and the environmental compartment are important. Results of this study in terms of demonstrating that paper curriencies or banknotes circulating in society can potentially mediate the transport of microorganisms among people and poses a risk to public health and it is also very important to highlight the need for proper hygienic practices for maximally reducing the spread of disease-causing pathogens. This can be considered as an indication that banknotes may contribute to the spread of pathogens and antimicrobial resistance. In this study, it was aimed to pay attention to hand hygiene for reducing the microbial load on the currencies and the necessity of producing these banknotes with maintain less bacteria such as plastic etc. instead of cotton. In addition, our study has been the first research to identified staphylococcus species and its virulance genes unlike other researches on this topic.

\section{FUNDING}

None to declare

\section{CONFLICT OF INTEREST}

The authors declare that they have no conflicts of interest

\section{REFERENCES}

1. Maritz JM, Sullivan SA, Prill RJ, Aksoy E, Scheid P, Carlton JM. Filthy lucre: A metagenomic pilot study of microbes found on circulating currency in New York City. PLoS One. 2017;12:e0175527. doi: 10.1371/journal.pone.0175527

2. Girma G. Health Risk Associated with Handling of Contaminated Paper Currencies in Circulation: A review. American Scientific Research Journal for Engineering, Technology, and Sciences (ASRJETS) 2014;10:40-53. [cited 11 November 2019]. Available from: http://asrjetsjournal.org/index.php/American_Scientific_Journal/ article/view/696.

3. Vriesekoop F, Chen J, Oldaker J, Besnard F, Smith R, Leversha W, et al. Dirty Money: A Matter of Bacterial Survival, Adherence, and Toxicity. Microorganisms 2016;4:E42 doi: 10.3390/microorganisms 4040042.

4. Que YA, Moreillon P. Staphylococcus aureus (Including Staphylococcal Toxic Shock Syndrome). In Mandell, Douglas, and Bennett's Principles and Practice of Infectious Diseases. Eighth Edition. Churchill Livingstone Elsevier. 2015; p 2237-71.

5. Ciupescu LM, Auvray F, Nicorescu IM, Meheut T, Ciupescu V, Lar$\operatorname{deux}$ A et al. Characterization of Staphylococcus aureus strains and evidence for the involvement of non-classical enterotoxin genes in food poisoning outbreaks. FEMS Microbiol Lett. 2018;365(13). doi: 10.1093/femsle/fny139.

6. Nanoukon C, Affolabi D, Keller D, Tollo R, Riegel P, Baba-Moussa L, et al. Characterization of Human Type $C$ Enterotoxin Produced by 
Clinical S. epidermidis Isolates. Toxins (Basel). 2018;10:E139. doi: 10.3390/toxins10040139.

7. Podkowik M, Seo KS, Schubert J, Tolo I, Robinson DA, Bania J, et al. Genotype and enterotoxigenicity of Staphylococcus epidermidis isolate from ready to eat meat products. Int J Food Microbiol. 2016;229:52-9. doi: 10.1016/j.ijfoodmicro.2016.04.013.

8. Nunes RSC, Aguila EMD, Paschoalin VMF. Safety Evaluation of the Coagulase-Negative Staphylococci Microbiota of Salami: Superantigenic Toxin Production and Antimicrobial Resistance. Biomed Res Int. 2015;483548. doi: 10.1155/2015/483548

9. Angelakis E, Azhar El, Bibi F, Yasir M, Al-Ghamdi AK, Ashshi AM, et al. Paper money and coins as potential vectors of transmissible disease. Future Microbiol. 2014; 9:249-61. doi: 10.2217/fmb.13.161.

10. Rocha-Gámez J, Tejeda-Villarreal PN, Macias-Cárdenas P, Canizales-Oviedo J, Garza-González E, Ramírez-Villarreal EG. Microbial contamination in 20-peso banknotes in Monterrey, Mexico. J Environ Health 2012;75:20-3. [cited 11 November 2019]. Available from: https://www.jstor.org/stable/26329464?seq=1\#metadata_ info_tab_contents.

11. EUCAST. The European Committee on Antimicrobial Susceptibility Testing. Routine and extended internal quality control for MIC determination and disk diffusion as recommended by EUCAST. Version 6.1, 2016. [cited 11 November 2019]. Available from: http:// www.eucast.org.

12. McDonald RR, Antonishyn NA, Hansen T, Snook LA, Nagle E, Mulvey MR, et al. Development of a Triplex Real-Time PCR Assay for Detection of Panton-Valentine Leukocidin Toxin Genes in Clinical Isolates of Methicillin-Resistant Staphylococcus aureus. J Clin Microbiol 2005;43:6147-49. doi: 10.1128/JCM.43.12.61476149.2005.

13. Khan SA, Nawaz MS, Khan AA, Hopper SL, Jones RA, Cerniglia CE. Molecular characterization of multidrug-resistant Enterococcus spp. from poultry and dairy farms: detection of virulence and vancomycin resistance gene markers by PCR. Mol Cell Probes 2005;19:27-34. doi:10.1016/j.mcp.2004.09.001

14. Copur Cicek A, Saral A, Ozad Duzgun A, Yasar E, Cizmeci Z, Ozlem Balci $P$, et al. Nationwide study of Escherichia coli producing extended-spectrum $\beta$-lactamases TEM, SHV and CTX-M in Turkey. J Antibiot. 2013;66:647-50. doi: 10.1038/ja.2013.72.

15. Poirel L, Héritier $C$, Tolun V, Nordmann P. Emergence of oxacillinase-mediated resistance to imipenem in Klebsiella pneumoniae. Antimicrob Agents Chemother 2004; 48:15-22. doi: 10.1128/ AAC.48.1.15-22.2004.

16. Chiefari AK, Perry MJ, Kelly-Cirino K, Egan CT. Detection of Staphylococcus aureus enterotoxin production genes from patient samples using an automated extraction platform and multiplex real-time PCR. Mol Cell Probes. 2015;29:461-67. doi: 10.1016/j. mcp.2015.06.004.

17. Peck KR, Baek JY, Song JH, Ko KS. Comparison of genotypes and enterotoxin genes between Staphylococcus aureus isolates from blood and nasal colonizers in a Korean hospital. J Korean Med Sci. 2009;24:585-91. doi: 10.3346/jkms.2009.24.4.585.

18. Abd Alfadil NA, Suliman Mohamed M, Ali MM, El Nima EAl. Char- acterization of Pathogenic Bacteria Isolated from Sudanese Banknotes and Determination of Their Resistance Profile. Int J Microbiol. 2018;2018:4375164. doi:10.1155/2018/4375164

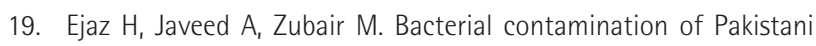
currency notes from hospital and community sources. Pak J Med Sci. 2018;34(5):1225-30. doi:10.12669/pjms.345.15477.

20. Pereira da Fonseca TA, Pessôa R, Sanabani SS. Molecular Analysis of Bacterial Microbiota on Brazilian Currency Note Surfaces. Int J Environ Res Public Health. 2015;12(10):13276-88. doi:10.3390/ ijerph121013276.

21. Kramer A, Schwebke I, Kampf G. How long do nosocomial pathogens persist on inanimate surfaces? A systematic review. BMC Infectious Diseases 2006;6:130. doi: 10.1186/1471-2334-6-130

22. Heshiki $Y$, Dissanayake $T$, Zheng $T$, Kang $K$, Yueqiong $N$, Xu Z et al. Toward a Metagenomic Understanding on the Bacterial Composition and Resistome in Hong Kong Banknotes. Front Microbiol. 2017;8:632. doi: 10.3389/fmicb.2017.00632.

23. Celik S, Koksal Cakırlar F, Mamal Torun M. Presence of Vancomycin, Aminoglycosides, and Erythromycin Resistance Genes in Enterococci Isolated from Clinical Samples in Turkey. Clin. Lab. 2014;60:1801-6. doi: 10.7754/clin.lab.2014.140211

24. Kacmaz B, Aksoy A. Antimicrobial resistance of Enterococci in Turkey. Int J Antimicrob Agents 2005;25:535-8. doi: 10.1016/j.ijantimicag.2005.02.020.

25. Akoachere JF, Gaelle N, Dilonga HM, Nkuo-Akenji TK. Public health implications of contamination of Franc CFA (XAF) circulating in Buea (Cameroon) with drug resistant pathogens. BMC Res Notes. 2014;8;7:16. doi: 10.1186/1756-0500-7-16.

26. Kliebe $\mathrm{C}$, Nies BA, Meyer JF, Tolxdorff-Neutzling RM, Wiedemann B. Evolution of plasmid-coded resistance to broad-spectrum cephalosporins. Antimicrob. Agents Chemother 1985;28:302-7. doi: 10.1128/aac.28.2.302.

27. Lahlaoui H, Ben Haj Khalifa A, Ben Moussa M. Epidemiology of Enterobacteriaceae producing CTX-M type extended spectrum $\beta$-lactamase (ESBL). Review. Med Mal Infect. 2014;44:400-4. doi: 10.1016/j.medmal.2014.03.010.

28. Canton R, Akova M, Carmeli Y, Giske CG, Glupczynski Y, Gniadkowski $M$ et al., Rapid evolution and spread of carbapenemases among Enterobacteriaceae in Europe. Clin Microbiol Infect 2012;18:413-31. doi: 10.1111/j.1469-0691.2012.03821.x.

29. Carrer A, Poirel L, Eraksoy H, Cagatay AA, Badur S, Nordmann P. Spread of OXA-48-positive carbapenem-resistant Klebsiella pneumoniae isolates in Istanbul, Turkey. Antimicrob Agents Chemother 2008;52:2950-4. doi: 10.1128/AAC.01672-07.

30. Albert NM, Bena JF, Ciudad C, Keleekai-Brapoh N, Morrison $\mathrm{SL}$, Rice $\mathrm{K}$, et al. Contamination of reusable electroencephalography electrodes: A multicenter study. Am J Infect Control. 2018;46(12):1360-4. doi: 10.1016/j.ajic.2018.05.021.

31. Oliveira D, Borges A, Simões M. Staphylococcus aureus Toxins and Their Molecular Activity in Infectious Diseases. Toxins (Basel). 2018;10(6):252. doi: 10.3390/toxins10060252. 